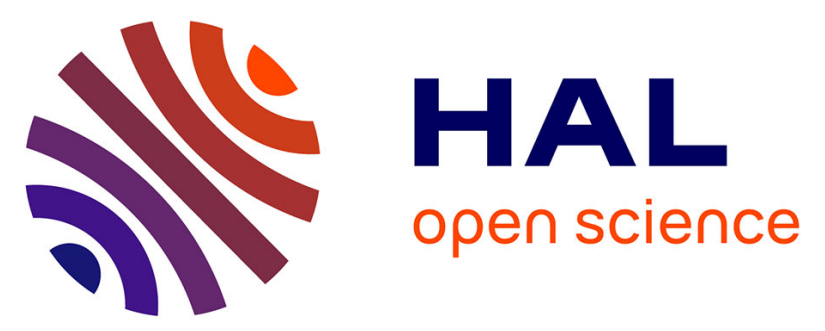

\title{
Treatment of Highly Virulent Extraintestinal Pathogenic Escherichia coli Pneumonia With Bacteriophages.
}

Nicolas Dufour, Laurent Debarbieux, Mélanie Fromentin, Jean-Damien Ricard

\section{To cite this version:}

Nicolas Dufour, Laurent Debarbieux, Mélanie Fromentin, Jean-Damien Ricard. Treatment of Highly Virulent Extraintestinal Pathogenic Escherichia coli Pneumonia With Bacteriophages.. Critical Care Medicine, 2015, 43 (6), pp.e190-8. 10.1097/CCM.0000000000000968 . pasteur-01539037

\section{HAL Id: pasteur-01539037}

\section{https://hal-pasteur.archives-ouvertes.fr/pasteur-01539037}

Submitted on 14 Jun 2017

HAL is a multi-disciplinary open access archive for the deposit and dissemination of scientific research documents, whether they are published or not. The documents may come from teaching and research institutions in France or abroad, or from public or private research centers.
L'archive ouverte pluridisciplinaire HAL, est destinée au dépôt et à la diffusion de documents scientifiques de niveau recherche, publiés ou non, émanant des établissements d'enseignement et de recherche français ou étrangers, des laboratoires publics ou privés.

\section{(1)(1) $\$(0)$}

Distributed under a Creative Commons Attribution - NonCommercial - ShareAlikel 4.0 


\section{Treatment of highly virulent extra-intestinal pathogenic Escherichia coli pneumonia with bacteriophages}

\section{Authors:}

Nicolas Dufour MD, MSc $\mathrm{MS}^{1,2,3,4}$, Laurent Debarbieux $\mathrm{PhD}^{1}$, Mélanie Fromentin $\mathrm{MSc}^{2}$, Jean-Damien Ricard MD, $\mathrm{PhD}^{2,3,4}$

1: Institut Pasteur, Molecular Biology of Gene in Extremophiles, Department of Microbiology, F75015 Paris, France

2 : Institut National de la Santé et la Recherche Médicale, INSERM, IAME, UMR 1137, F-75018, Paris, France

3: Univ Paris Diderot, IAME, UMR 1137, Sorbonne Paris Cité, F-75018 Paris, France

4: AP-HP, Hôpital Louis Mourier, Service de Réanimation Médico-chirurgicale, F-92700 Colombes, France

\section{Corresponding author:}

Prof Jean-Damien Ricard,

Service de Réanimation Médicale,

178 rue des Renouillers, F-92701 Colombes Cedex, France

Fax: + 33147606192

Phone: +33147606195

Email: jean-damien.ricard@Imr.aphp.fr

\section{Abstract word Count: 282}

Main text word count: 3881

Key words: nosocomial infections; bacteriophage; Escherichia coli; ventilator-associated pneumonia; lung infection; phage therapy. 


\section{Abstract}

Objective: To study the effect of bacteriophage treatment on highly virulent extra-intestinal $E$. coli pneumonia in mice and compare it to conventional antimicrobial treatment.

Design: Animal investigation.

Setting: University research laboratory.

Subjects: Pathogen-free 8 weeks old Balb/cJRj male mice.

Interventions: Two bacteriophages (536_P1 and 536_P7) were isolated from sewage using strain 536 , a highly virulent extra-intestinal E. coli. Their in vitro and in vivo efficacy against strain 536 and a ventilator-associated pneumonia (VAP) E. coli were tested. The first group of mice were infected by intranasal instillation of bioluminescent strain 536 and received either 536_P1 intranasally, ceftriaxone or control. The second group of mice was infected with the VAP strain and received 536_P7. Adaptation of 536_P7 to this clinical isolate was also evaluated in vitro and in vivo.

Measurements and Main Results: In vivo efficacy of bacteriophage and antibiotic treatment were assessed by recording bioluminescence for short time periods and by recording body weight and survival of mice for longer periods. Both treatments improved survival compared to control $(100 \%$ vs $0 \%$ ) and in vivo bioluminescence recordings showed a similar rapid decrease of emitted light suggesting prompt bacterial clearance. The majority of mice infected by the VAP strain were not rescued by treatment with 536_P7; however in vitro adaptation of this bacteriophage towards the VAP strain led to isolate a variant which significantly improved in vivo treatment efficacy (animal survival increased from 20 to $75 \%)$.

Conclusions: Bacteriophage treatment was as effective as antibiotherapy to provide $100 \%$ survival rate in a lethal model of highly virulent $E$. coli pneumonia. Adaptation of a bacteriophage is a rapid solution to improve its efficacy towards specific strains. These results suggest that phage therapy could be a promising therapeutic strategy for VAP. 


\section{Introduction}

Lower respiratory tract infections (i.e. pneumonia) represent the third leading cause of mortality in the world according to the WHO epidemiological data center (1) and the most frequent lifethreatening nosocomial infection in the intensive care unit. All patients undergoing invasive mechanical ventilation are indeed exposed to a time-dependent risk of ventilator-associated pneumonia (VAP). VAP is associated with an impaired prognosis, an increase in costs and probably also in mortality although recent studies have considerably lowered VAP attributable mortality (2-5). Two main factors directly impact treatment's efficacy of these infections and patients outcome: bacterial virulence and antibiotic resistance. In the United States, at least 23,000 death are directly linked to antibiotic resistant infections and the highest mortality is attributed to Enterobacteriaceae (mainly Klebsiella spp. and Escherichia coli) (6) .

In western countries, E. coli is responsible for ICU infections as often as Pseudomonas $(2,7)$. Recently, Enterobacteriaceae were found more frequently than $P$. aeruginosa in microbiologically documented VAP (8), E. coli being one of the most prevalent of them.

In the ICU setting, E. coli strains involved in VAP belong predominantly to the B2 phylogenetic group and possess a high number of virulence factors (9). Interestingly, a number of these strains belonged to subgroup III (Sequence Type 127) including the highly virulent archetypal strain 536 (10). Finally, E. coli is well-known to develop antibiotic resistance (11) and is then emerging as one of the greatest microbiological threat to come, urging the development of specific antibacterial treatments $(12,13)$, especially in the ICU setting.

In this context, bacteriophages may offer an interesting perspective and recent calls have been made to promote their use (14-16). Bacteriophages are viruses that infect specifically bacterial cells. They are unique among antibacterial agents in their ability to increase their number in presence of the bacterial target. During the last decade, a renewed interest for phage therapy has led to publication of several encouraging in vitro and in vivo studies (17-20). Several clinical trials (http://clinicaltrials.gov) have been initiated and the European Union has recently funded a large randomized controlled trial to test the efficacy of phage therapy to treat infected burn wounds (http://www.phagoburn.eu).

In this article, we investigated the use of bacteriophages to treat pneumonia induced by highly virulent extra-intestinal pathogenic E. coli. Using in vivo kinetics assessed by bioluminescence recording we showed that phage therapy is as effective as antibiotics. Additional observations 
demonstrate the flexibility of bacteriophage adaptation which represents a rapid and easy way to improve bacteriophage efficacy towards clinical strains.

\section{Material and methods}

\section{Escherichia coli strains}

Both strains, E. coli 536 (10) and PDP302, belong to the B2 phylogenetic group of highly virulent extra-intestinal E. coli, determined by the triplex PCR technique (21). Strain PDP302 was isolated from an ICU patient under mechanical ventilation who developed a ventilator-associated pneumonia and belongs to a well characterized collection (9).

The 536-lux strain was obtained by transformation of the wild type 536 strain with plasmid pCM17. pCM17 carries the kanamycin resistance gene and the luxCDABE operon from Photorhabdus luminescens under $O m p C$ promoter for a constitutive expression $(22,23)$. Stability over time of the light emitting phenotype without antibiotic pressure has been checked by means of repeated seeding of liquid cultures over 10 days. Quantification and analysis of luminescence, both on liquid and solid medium showed that the light produced started to decrease only after the $7^{\text {th }}$ day of intense growth conditions (see supplemental digital content, SDC page 1 and 2).

\section{Bacteriophages isolation, preparation, adaptation and sequencing}

Bacteriophages 536_P1 and 536_P7 were isolated from sewage using strain 536 as previously described $(20,24)$.

In vitro activity of a given bacteriophage on a non-host strain was assessed by its efficiency of plaquing (EOP). The term "non-host strain" refers to a strain which was not the one used to isolate the bacteriophage. EOP was calculated as the ratio of number of plaques formed by the bacteriophage on the non-host strain to the number of plaques formed on its host, using the same bacteriophage solution (see SDC, page 2 and 3 ).

Bacteriophage 536_P1 and 536_P7 displayed an EOP of 1 on 536-lux strain (compared to wild type 536). Bacteriophage 536_P7 displayed an EOP of 1 on strain PDP302 (see SDC). Heat inactivated 536_P1 was obtained after incubation at $80^{\circ} \mathrm{C}$ for 10 minutes (total loss of infectivity was then confirmed by titration).

We adapted bacteriophage 536_P7 to strain PDP302 to improve its virulence against this strain. It is indeed known, since the pioneered works of Felix d'Herelle in 1917 (25) that the amplification of bacteriophages on a bacterial strain different (but close enough) to the original host (initially used to isolate them), can lead to select bacteriophage variants which could display increased infectivity 
towards this different strain. The in vitro adaptation of bacteriophage 536_P7 to strain PDP302 was performed as follows: a liquid culture of strain PDP302 (50 mL, in LB broth) was infected by bacteriophage 536_P7 at multiplicity of infection (MOI) of $10^{-3}$ (i.e. a ratio of virus to bacteria equal to 0.001 ) for 3 hours. Then, $5 \mathrm{~mL}$ were centrifuged 5 minutes at $8000 \mathrm{~g}$ and the supernatant was sterilized by filtration. A fraction of this lysate was titrated on both parental (536) and targeted (PDP302) strains before infecting a new $50 \mathrm{~mL}$ PDP302 liquid culture. These steps were repeated 4 times ending with plaque isolation (24) to purify the adapted bacteriophage, called 536_P7_PDP302. Kinetics of lysis of strain PDP302 by bacteriophages 536_P7 and 536_P7_PDP302 were performed in 96 wells plate (see SDC, page 3).

All bacteriophages solutions were purified as described previously using cesium chloride gradient ultracentrifugation (26). Transmission electron microscopy observations were performed following uranyl acetate staining (photograph of bacteriophages 536_P1 and 536_P7 are supplied in the SDC, page 4).

Sequencing of bacteriophage 536_P1 and 536_P7 was performed using Illumina ${ }^{\circledR}$ sequencing technology. DNA was extracted from lysates, using a DNase and RNase pretreatment followed by a phenol-chloroform extraction method, modified from Pickard (27). Genome of 536_P1 (149 471 bp) was found $99 \%$ identical on $90 \%$ of its length to phAPEC8 bacteriophage (28). Genome of 536_P7 (148 442 bp) was found $98 \%$ identical on $93 \%$ of its length to phi92 bacteriophage (29).

\section{Animals and Ethics statement}

Eight-week-old BALB/CJRj male mice (Janvier, France) were housed in animal facility in accordance with French and European regulations on the care and protection of laboratory animals. Protocols were approved by the veterinary staff of the Institut Pasteur animal facility (approval number 10.565) and the National Ethics Committee regulating animal experimentation (approval number 2012-0018). Intraperitoneal administration of $1.25 \mu \mathrm{g}\left(50 \mathrm{\mu g} / \mathrm{Kg}\right.$ ) of buprenorphine (Buprecare ${ }^{\circledR}$, AST Farma, The Netherlands) was systematically performed on all mice at 8 and 24 hours post-infection to limit pain and dyspnea. Food and drink were provided ad libitum.

\section{Animal infection and treatment, bioluminescence recording}

Mice, anesthetized with a mixture of ketamine and xylazine administered via intra-muscular route, were infected intranasally with $1 \times 10^{7}$ (non $100 \%$ lethal dose) or $4 \times 10^{7}$ CFU (100\% lethal dose) of 536lux strain or by $1.5 \times 10^{7} \mathrm{CFU}$ (non $100 \%$ lethal dose) of PDP302 strain, resuspended in $20 \mu \mathrm{L}$ of PBS (phosphate buffered saline). Two hours later, mice were anesthetized by isoflurane inhalation (2\%) or by a second intra-muscular injection of ketamine/xylazine. Mice then received a second $20 \mu \mathrm{L}$ 
intranasal administration of PBS (control group) or $20 \mu \mathrm{L}$ of the therapeutic bacteriophage solution (in PBS) with a multiplicity of infection (MOI) of $0.3,3$ or 10 . Mice were weighed daily (and euthanized if weight loss was greater than 25\%, a limit never reached in the present experiments) and visited twice daily to assess behavior and mortality for at least 14 days. Ceftriaxone sodium (TEVA, France) was suspended in normal saline. A $50 \mathrm{mg} / \mathrm{Kg}$ dose $(1250 \mu \mathrm{g}, 200 \mu \mathrm{L})$ was injected intraperitoneally 2 hours post-infection and every 12 hours during 2 days (i.e. a total of 5 injections). In parallel, control group received $200 \mu \mathrm{L}$ injections of normal saline. Ceftriaxone minimal inhibitory concentration (MIC) for the 536-lux strain was inferior to $0.03 \mathrm{mg} / \mathrm{L}$ (according to standardized disk diffusion method).

Photon emission of the luminescent bacteria was recorded and analyzed as previously described (20) using an Ivis Spectrum imaging system (PerkinElmer, California, USA) and a dedicated software (Living Image, PerkinElmer). Amount of photon emitted was expressed as photon $/ \mathrm{sec} / \mathrm{cm}^{2} / \mathrm{steradian}$ and normalized by subtracting the background luminescence noise using a non-infected control mouse included in each recording. A typical recording is shown in Figure 1.

\section{Bacteriophage and bacterial counts in lung homogenate, analysis of bronchoalveolar lavage (BAL)} fluids

These analyses were performed independently from experiments assessing mortality and bioluminescence signal, using 4 mice per condition and per time point. Lungs were removed from euthanized mice at 2, 6 and 16 hours post-infection, weighed and mechanically homogenized (UltraTurrax, IKA, Germany) before being serially diluted to count colony of strain 536 on agar plate containing kanamycin (triplicate) and count plaques of bacteriophage 536-P1 on agar plates covered with strain 536 (triplicate).

BALs procedure and processing of BAL fluids for cytological (cell counts, microscopic observations) and biochemical analysis (total proteins, lactate dehydrogenase and KC levels) were performed as detailed in the SDC (page 4).

\section{Statistical analysis}

All statistical analyses were performed by using GraphPad Prism version 5.00 (GraphPad Software, California, USA). The normal distribution of all variables was checked using the Kolmogorov-Smirnov test and results are then expressed as means \pm standard deviation. In case of non-Gaussian distribution, results are expressed as median [25th ; 75th percentile]. Statistical tests (Student's t-test or Mann-Whitney test) were chosen accordingly. Survival curves were compared by using the Logrank test. Comparison of proportion was performed using Fisher's exact test. A p value less than 0.05 was considered as statistically significant. 


\section{Results}

\section{Treatment of E. coli 536-lux pneumonia with bacteriophage 536_P1}

All mice ( $n=32$, two independent experiments) challenged with $1 \times 10^{7}$ CFU of E. coli 536-lux exhibited an acute weight loss with a maximum 3 days after bacterial inoculation $(-12.0 \pm 4.8 \%)$, followed by a gradual recovery (baseline weight values were reached by day 7, see SDC, page 5). Mortality was $75 \%$ in the control group ( $n=16,4$ survivors). By striking contrast, $100 \%$ of mice treated with bacteriophage 536_P1 with a multiplicity of infection (MOI, see methods) of $0.3(n=8)$ or $3(n=8)$ survived (Figure 2, graph A). Luminescence quantification of the mice lungs area revealed that amount of light emitted was not different within the first 4 hours post-infection but became significantly lower in the bacteriophage-treated mice as early as 6 hours post-infection (i.e. 4 hours after the beginning of treatment; $5.0 \times 10^{3}\left[1.5 \times 10^{3} ; 6.7 \times 10^{3}\right]$ vs $2.0 \times 10^{4}\left[1.6 \times 10^{4} ; 3.1 \times 10^{4}\right]$ $\mathrm{p} / \mathrm{sec} / \mathrm{cm}^{2} / \mathrm{ste} ; \mathrm{p}<0.005 ;$ Figure 3, graph A).

\section{Microbiological and cytological analysis of lung homogenates and BAL fluids}

In a second set of two independent experiments, we quantified levels of bacteria, bacteriophages, cytokines and cell markers in both PBS and bacteriophage-treated mice at 6 and 16 hours after initiating lung infection (Table 1). Bacterial counts were lower in the 536_P1-treated group than in the control group, reaching a difference greater than $2 \log _{10}$. Given that bacteriophages cannot increase without bacterial lysis, bacteriophage counts were also in agreement with these data and we observed an increase of the viral population of $1.1 \log _{10}$ between 6 and 16 hours post-infection. In addition, the proportion of polymorphonuclears (PMN) as well as the level of chemokine KC (CXCL1) were reduced in the bacteriophage-treated group 16 hours post-infection (Table 1). We also observed that BAL fluids from 536_P1-treated mice contained very few images of engulfed bacteria within PMN or monocyte-macrophages compared to control mice (Table 1, see also representative pictures in SDC page 5-7).

Total protein counts did not differ between treated and control mice. There was a trend toward lower levels of LDH in the 536_P1 treated group $(p=0.10)$.

\section{Comparison of E. coli 536-lux pneumonia treatment with either bacteriophage 536_P1 or ceftriaxone}

In a third set of two independent experiments, all mice $(n=28)$ were challenged with a higher inoculum ( $4 \times 10^{7} \mathrm{CFU}$ of $E$. coli 536 -lux) leading to $100 \%$ lethal infection. Only treated mice were alive at day 3 and exhibited a greater weight loss $(-18.5 \pm 0.8 \%, p<0.001)$ than during the set of experiment 
performed with a $1 \times 10^{7} \mathrm{CFU}$ inoculum. Despite this, they presented the same recovery pattern (see SDC, page 5). Mortality at day 3 was $100 \%$ in the control group ( $n=14$, Figure 2 , graph B). Survival was $100 \%$ in both bacteriophage-treated mice $(n=8, \mathrm{MOI}$ of 3 ) and ceftriaxone-treated mice $(n=6)$. Within the first 48 hours post-infection, quantification of light emitted from lungs revealed that bacteriophage 536_P1 and ceftriaxone-treated groups led to an identical decrease of the signal, whether it be in terms of kinetic (slope) or raw values (Figure 3, Graph B).

\section{In vitro adaptation of bacteriophages 536_P7 is required to reach efficient pneumonia treatment}

Next, we searched for an E. coli VAP strain displaying equivalent characteristic to the archetypal strain 536 and identified strain PDP302 from our collection (9). In vitro, this clinical strain was as efficiently infected by bacteriophage 536_P7 as strain 536 (EOP of 1, see methods and SDC). Once

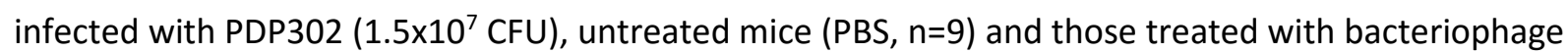
536_P7 ( $n=10, \mathrm{MOI}$ of 10 ) displayed respectively a $88 \%$ and $80 \%$ mortality rate (two independent experiments). We then hypothesized that serial in vitro passages of 536_P7 bacteriophage on strain PDP302 could improve its in vivo infectivity towards this strain.

Treatment with 536_P7_PDP302, the resulting adapted bacteriophage isolated after 5 serial passages (see methods), was associated with a significant increase in survival $(75 \%, p=0.001, n=8, M O$ of 10 ; Figure 4). While agar plate assays were not able to differentiate 536_P7 and 536_P7_PDP302 bacteriophages (no gain in EOP), the in vivo improvement observed was in agreement with data obtained from lysis kinetics assays (see Figure 5 and SDC). Indeed, with 536_P7_PDP302 the optical density reached 0.085 in 90 minutes before lysis occurred while it reached 0.162 in 105 minutes with 536_P7.

\section{Discussion}

In this study we showed for the first time that experimental E. coli pneumonia was efficiently treated by bacteriophages. Its main results can be summarized as follows: i) bacteriophage treatment enabled $100 \%$ survival of mice lethally infected with highly virulent extra-intestinal $E$. coli strain 536 ; ii) It was associated with a significant decrease in lung inflammation; iii) it appeared to be as effective as ceftriaxone antibiotic treatment reaching $100 \%$ survival; iv) it decreased bacterial load in the lungs in a comparable manner as ceftriaxone treatment; v) in vivo bacteriophages efficacy could be rapidly enhanced by in vitro adaptation toward the targeted strain.

In this work, we focused on E. coli for the following reasons: i) oropharyngeal colonization with Enterobacteriaceae has been long known as the first step toward Gram negative bacteria VAP (30, 
31 ); ii) recent data suggest that Enterobacteriaceae (including E. coli) are increasingly responsible for VAP, ahead of $P$. aeruginosa and Staphylococcus aureus (8, 32); iii) Enterobacteriaceae in general and E. coli in particular represent the major threat in terms of antimicrobial resistance, including VAP (33). We recently reported that $E$. coli strains infecting ICU patients closely resembled the highly virulent archetypal ExPEC strain 536 in terms of phylogenetic grouping, virulence factors, genes content and in vivo virulence $(9,10)$. To complete this proof of concept study, we reasoned it was necessary to also assess the efficacy of bacteriophage on strain PDP302, a clinical strain responsible for a VAP in an ICU patient. Strain PDP302 was one of the infrequent strain (10 tested) to be pathogenic for mice in our lung infection model and interestingly, this strain turned out to share the same sequence type (ST127) as strain 536 (i.e. same clonal complex, ST127 being one of the most prominent sequence type within ExPEC). This observation fully illustrates the correlation that exists between sequence type and pathogenicity (34).

The observed therapeutic effect was due to rapid bacterial clearance, as suggested by the rapid decrease in bioluminescence signal in the lungs (Figure 3) and confirmed by direct bacterial count 6 hours post-infection. Next, we compared, for the first time in such model, efficacy of bacteriophage treatment to conventional antibiotherapy. Both treatments displayed striking resemblance in terms of kinetics (Figure 3, Graph B) and both rescued $100 \%$ of lethally infected animals. In this regard, it should also be noted that we deliberately used a high dose ceftriaxone treatment $(100 \mathrm{mg} / \mathrm{Kg} / \mathrm{day}$ with repeated administrations), a molecule to which E. coli 536 is highly sensitive (CMI $<0.03 \mathrm{mg} / \mathrm{L}$ ) to ensure maximum efficacy of the antimicrobial treatment and to avoid any bias in favor of the bacteriophage-treated group. We also observed that 16 hours after infection, bacteriophage-treated mice displayed less lung inflammation compared to untreated mice based on KC (CXCL-1) cytokine level. This data corroborated with cytological observations since phagocytic cells present in BAL fluids were virtually free of intracellular bacteria in bacteriophage-treated mice. We also found an increased number of monocytes-macrophages in BAL fluids of bacteriophage-treated mice 16 hours post-infection (that we interpreted as the beginning of a resolution phase) but we did not perform phenotype analysis to check the precise part of resident cells (i.e. alveolar macrophages) and recruited ones (i.e. monocytes). Indeed, the latter could promote specific changes in local inflammatory balance (35). However, in our case, given the minimal increase observed, even if statistically significant, the physiological relevance could be weak at this time point.

In this work, we observed in vitro / in vivo bacteriophages efficacy discrepancies. These disparities that have been described a long time ago with antibiotics (36) have also, although more recently, been reported with bacteriophages $(37,38)$. However, in striking contrast to antibiotic optimization that requires months if not years of research, bacteriophages can evolve very quickly (hours to days) 
enabling them to eventually adapt to a given targeted bacteria. We clearly show that this adaptation can lead to a considerable gain in efficacy, as mortality decreased from $80 \%$ to $25 \%$ when using an adapted bacteriophage. The adaptation procedure used was based on evolution of population where the most efficient bacteriophages are favored. After each passage, during which 536_P7 bacteriophage was infecting strain PDP302, a fraction of the evolved viral population was submitted to the next round. After 5 rounds, bacteriophages from a plaque-forming unit were amplified and purified to establish the adapted 536_P7_PDP302 bacteriophage population.

Previous studies focusing on bacteria-bacteriophages interactions have already described several mechanisms by which bacteriophages may improve their infectivity. These include increase in adsorption capability achieved by receptor variation (39-42), increase in number of released viruses (43), shortening of latent period and improvement of resistance to bacterial defense against virus invasion using anti-CRISPR system $(44,45)$. It should also be noted that the adaptation procedure performed in vitro is not an absolute guarantee to drive the selection of a bacteriophage variant toward in vivo improved efficacy (37).

This study has some potential limitations. First, one could argue that treatment with bacteriophages was administered shortly after bacterial challenge ( 2 hours). This delay is within the same order of magnitude than that of other models of acute infection with different pathogens (mainly E. coli, $S$. pneumonia and $K$. pneumoniae), varying between 1 and 4 hours (46-49). This takes into account the fact that, contrary to the clinical scenario, pneumonia develops within hours of a large and single bacterial inoculation, as demonstrated by the kinetic of the bioluminescence signal. We however cannot rule out that a delayed treatment (bacteriophage as well as antibiotic-based) could be less efficient.

Second, some could question the applicability of phage therapy to the ICU because of time constraints to obtain a specific bacteriophage against the identified bacteria. There are in fact two arguments that on the contrary, support the use of bacteriophages in ICU: i) based on the epidemiological surveillance of clinical strains sampled over the years in hospitals, it is possible to elaborate cocktails of several ready to use bacteriophages, thereby extending host spectrum (50), ii) most importantly, because oropharyngeal colonization precedes nosocomial pneumonia (51), it will be possible right from the beginning, to select bacteriophages against the bacteria (eventually including an adaptation step as described in our study) and have the treatment available when the infection occurs. Finally, administering bacteriophages once colonization is detected may be a means to prevent secondary infection.

Third, caution is required regarding the extrapolation of our experimental results to the clinical setting of mechanical ventilation. Obviously they serve as a proof of concept and whether similar 
results will be obtained in mechanically ventilated lungs, within pre-existing inflammation and possible injury will need to be addressed in future studies.

Finally, a possible toxicity related to bacteriophage therapy can be questioned. First of all, it is important to recall that bacteriophages are not foreign to the human being, since we harbour a vast amount of bacteriophages, mainly in our intestinal tract and mucous membranes (52). We also eat and drink each day thousands of bacteriophages without experiencing any trouble (53). Second, contrary to viruses used in viral gene therapy, bacteriophages are unable to penetrate eukaryotic cells. Third, from an immunological point of view, bacteriophages do not elicit a significant acute inflammatory response in mammals as shown by several studies on both purified structural proteins and entire virions $(17,54)$. In our work, we observed a non-significant increase in BAL fluid total proteins in bacteriophage-treated mice compared to control mice 6 hours post-infection (208 and $140 \mu \mathrm{g} / \mathrm{mL}$, respectively). Importantly, this difference was not confirmed at H16 (304 and $320 \mu \mathrm{g} / \mathrm{mL}$, respectively) while the amount of bacteriophages increased (Table 1). We therefore believe that these non-significant differences reflect sampling fluctuation rather than differences in lung permeability (in addition, LDH activity is identical in both group at $\mathrm{H} 6$ and tends to be weaker in bacteriophage-treated mice at $\mathrm{H} 16)$.

This absence of acute immunological response should be distinguished from the long-lasting humoral immunity where, conversely, bacteriophages have been shown to be able to induce specific antibodies production (55). Although not harmful for the host, these antibodies could be problematic if a repeated administration of the bacteriophage is planned because these antibodies could be neutralizing.

Many reviews have listed pros and cons of phage therapy (56) which is beyond the scope of this work. We can however mention that bacteriophages reported here fit well into a consensus which indicates that all candidate bacteriophages should be sequenced (in order to discard those which carry putative unwelcome genes, mainly toxins and antibiotic resistance genes) and when possible, the most infective bacteriophages (based on in vitro assessment) should be chosen.

Facing growing bacterial resistance to antibiotics, urgent measures need to be taken both to spare antibiotics and to investigate new therapeutic strategies. Amongst putative solutions, use of bacteriophages is the only one to have been widely used in the past in humans (57). Regarding lung infection, bacteriophage treatment of experimental $P$. aeruginosa pneumonia with strains isolated in cystic fibrosis patients or Klebsiella infection also proven to be effective $(18,20,37,58,59)$. For all of the above reasons and because patients in the ICU are among the most exposed to the threat of resistant pathogens (and therefore under close bacterial surveillance), the ICU setting seems to be particularly appropriate for phage therapy to fight bacterial infections. This is in agreement with 
recent calls to promote the use of phage therapy to overcome antibioresistance, to limit antibiotic selective pressure and protect natural commensals (14-16). Our results provide then the first evidence that bacteriophage therapy could be part of the nosocomial pneumonia treatment.

\section{Acknowledgments}

We thank Pr. James Kaper (University of Maryland School of Medicine, Baltimore) for the gift of pCM17 and Jonathan Messika for the PDP302 strain.

We thank Marie-Anne Nicola (Imagopole, Institut Pasteur) for her technical assistance and all members of the animal housing facility for their help in mice management.

We also express our gratefulness to Chantal Archambeau and Estelle Atse for logistics support and media preparation.

\section{Funding}

This work was supported by a joint research grant from both Institut Pasteur and Assistance Publique - Hôpitaux de Paris (Programme Transversal de Recherches $n^{\circ} 417$ ). Nicolas Dufour is the recipient of a Poste d'Accueil attributed by Assistance Publique - Hôpitaux de Paris and Institut Pasteur.

\section{Bibliography}

1. World Health Organization. The 10 leading causes of death by broad income group. 2008 [cited 2013 june]Available from: http://www.who.int/mediacentre/factsheets/fs310/en/index.html

2. Fagon JY, Chastre J, Hance AJ, et al. Nosocomial pneumonia in ventilated patients: a cohort study evaluating attributable mortality and hospital stay. Am J Med 1993;94(3):281-288.

3. Heyland DK, Cook DJ, Griffith L, et al. The attributable morbidity and mortality of ventilatorassociated pneumonia in the critically ill patient. The Canadian Critical Trials Group. Am J Respir Crit Care Med 1999;159(4 Pt 1):1249-1256.

4. Kollef $\mathrm{MH}$. Ventilator-associated pneumonia. A multivariate analysis. JAMA 1993;270(16):1965-1970.

5. Torres A, Aznar R, Gatell JM, et al. Incidence, risk, and prognosis factors of nosocomial pneumonia in mechanically ventilated patients. Am Rev Respir Dis 1990;142(3):523-528.

6. Center for Disease Control. Antibiotic resistance threats in the United States. 2013 [cited 2014 march]Available from: http://www.cdc.gov/drugresistance/threat-report-2013 
7. Vincent JL, Rello J, Marshall J, et al. International study of the prevalence and outcomes of infection in intensive care units. JAMA 2009;302(21):2323-2329.

8. Hamet M, Pavon A, Dalle F, et al. Candida spp. airway colonization could promote antibioticresistant bacteria selection in patients with suspected ventilator-associated pneumonia. Intensive Care Med 2012;38(8):1272-1279. doi: 1210.1007/s00134-00012-02584-00132. Epub 02012 Jun 00115.

9. Messika J, Magdoud F, Clermont O, et al. Pathophysiology of Escherichia coli ventilatorassociated pneumonia: implication of highly virulent extraintestinal pathogenic strains. Intensive Care Med 2012;38(12):2007-2016.

10. Brzuszkiewicz $\mathrm{E}$, Bruggemann $\mathrm{H}$, Liesegang $\mathrm{H}$, et al. How to become a uropathogen: comparative genomic analysis of extraintestinal pathogenic Escherichia coli strains. Proc Natl Acad Sci U S A 2006;103(34):12879-12884. Epub 12006 Aug 12815.

11. Lynch JP, Clark NM, Zhanel GG. Evolution of antimicrobial resistance among Enterobacteriaceae (focus on extended spectrum beta-lactamases and carbapenemases). Expert Opin Pharmacother 2013;14(2):199-210.

12. Ricard JD. New therapies for pneumonia. Curr Opin Pulm Med 2012;18(3):181-186. doi: 110.1097/MCP.1090b1013e3283520fec.

13. Roux D, Ricard JD. Novel therapies for Pseudomonas aeruginosa pneumonia. Infect Disord Drug Targets 2011;11(4):389-394.

14. Fauci AS, Marston HD. The Perpetual Challenge of Antimicrobial Resistance. JAMA 2014;20(10).

15. Brussow $\mathrm{H}$. What is needed for phage therapy to become a reality in Western medicine? Virology 2012;434(2):138-142. doi: 110.1016/j.virol.2012.1009.1015. Epub 2012 Oct 1019.

16. Matsuzaki S, Uchiyama J, Takemura-Uchiyama I, et al. Perspective: The age of the phage. Nature 2014;509(7498):S9. doi: 10.1038/1509S1039a.

17. Carmody LA, Gill JJ, Summer EJ, et al. Efficacy of bacteriophage therapy in a model of Burkholderia cenocepacia pulmonary infection. J Infect Dis 2010;201(2):264-271. doi: 210.1086/649227.

18. Chhibber S, Kaur S, Kumari S. Therapeutic potential of bacteriophage in treating Klebsiella pneumoniae B5055-mediated lobar pneumonia in mice. J Med Microbiol 2008;57(Pt 12):1508-1513.

19. Chhibber S, Kaur T, Sandeep K, et al. Co-therapy using lytic bacteriophage and linezolid: effective treatment in eliminating methicillin resistant Staphylococcus aureus (MRSA) from diabetic foot infections. PLoS One 2013;8(2):e56022. doi: 56010.51371/journal.pone.0056022. Epub 0052013 Feb 0056013.

20. Debarbieux L, Leduc D, Maura D, et al. Bacteriophages can treat and prevent Pseudomonas aeruginosa lung infections. J Infect Dis 2010;201(7):1096-1104.

21. Clermont O, Bonacorsi S, Bingen E. Rapid and simple determination of the Escherichia coli phylogenetic group. Appl Environ Microbiol 2000;66(10):4555-4558.

22. Morin CE, Kaper JB. Use of stabilized luciferase-expressing plasmids to examine in vivoinduced promoters in the Vibrio cholerae vaccine strain CVD 103-HgR. FEMS Immunol Med Microbiol 2009;57(1):69-79.

23. Rhee KJ, Cheng $\mathrm{H}$, Harris $\mathrm{A}$, et al. Determination of spatial and temporal colonization of enteropathogenic $E$. coli and enterohemorrhagic $E$. coli in mice using bioluminescent in vivo imaging. Gut Microbes 2011;2(1):34-41.

24. Van Twest R, Kropinski AM. Bacteriophage enrichment from water and soil. Methods Mol Biol 2009;501:15-21.(doi):10.1007/1978-1001-60327-60164-60326_60322.

25. d'Herelle F. Sur un microbe invisible antagoniste des bacilles dysentériques. Compte rendus de l'académie des sciences de Paris 1917;165:373-375.

26. Boulanger P. Purification of bacteriophages and SDS-PAGE analysis of phage structural proteins from ghost particles. Methods Mol Biol 2009;502:227-238.

27. Pickard DJ. Preparation of bacteriophage lysates and pure DNA. Methods Mol Biol 2009;502:3-9.(doi):10.1007/1978-1001-60327-60565-60321_60321. 
28. Tsonos J, Adriaenssens EM, Klumpp J, et al. Complete genome sequence of the novel Escherichia coli phage phAPEC8. J Virol 2012;86(23):13117-13118. doi: 13110.11128/JVI.0237413112.

29. Kwiatkowski B, Boschek B, Thiele $\mathrm{H}$, et al. Substrate specificity of two bacteriophageassociated endo-N-acetylneuraminidases. J Virol 1983;45(1):367-374.

30. Johanson WG, Pierce AK, Sanford JP. Changing pharyngeal bacterial flora of hospitalized patients. Emergence of gram-negative bacilli. N Engl J Med 1969;281(21):1137-1140.

31. Johanson WG, Jr., Pierce AK, Sanford JP, et al. Nosocomial respiratory infections with gramnegative bacilli. The significance of colonization of the respiratory tract. Ann Intern Med 1972;77(5):701-706.

32. Ricard JD, Roux D. Candida colonization in ventilated ICU patients: no longer a bystander! Intensive Care Med 2012;38(8):1243-1245. doi: 1210.1007/s00134-00012-02587-z. Epub 02012 Jun 00115.

33. Ho WS, Gan HM, Yap KP, et al. Genome sequence of multidrug-resistant Escherichia coli EC302/04, isolated from a human tracheal aspirate. J Bacteriol 2012;194(23):6691-6692. doi: 6610.1128/JB.01804-01812.

34. Kohler CD, Dobrindt U. What defines extraintestinal pathogenic Escherichia coli? Int J Med Microbiol 2011;301(8):642-647. doi: 610.1016/j.ijmm.2011.1009.1006. Epub 2011 Oct 1015.

35. Herold S, Tabar TS, Janssen $\mathrm{H}$, et al. Exudate macrophages attenuate lung injury by the release of IL-1 receptor antagonist in gram-negative pneumonia. Am J Respir Crit Care Med 2011;183(10):1380-1390. doi: 1310.1164/rccm.201009-2014310C. Epub 202011 Jan 201028.

36. Greenwood D. In vitro veritas? Antimicrobial susceptibility tests and their clinical relevance. J Infect Dis 1981;144(4):380-385.

37. Henry $M$, Lavigne $R$, Debarbieux L. Predicting in vivo efficacy to guide the choice of therapeutic bacteriophages to treat pulmonary infections. Antimicrob Agents Chemother 2013.

38. Bull JJ, Otto G, Molineux IJ. In vivo growth rates are poorly correlated with phage therapy success in a mouse infection model. Antimicrob Agents Chemother 2012;56(2):949-954.

39. Duplessis M, Levesque CM, Moineau S. Characterization of Streptococcus thermophilus host range phage mutants. Appl Environ Microbiol 2006;72(4):3036-3041.

40. Qimron U, Marintcheva B, Tabor S, et al. Genomewide screens for Escherichia coli genes affecting growth of T7 bacteriophage. Proc Natl Acad Sci U S A 2006;103(50):19039-19044. Epub 12006 Nov 19029.

41. Ravin V, Raisanen L, Alatossava T. A conserved C-terminal region in Gp71 of the small isometric-head phage LL-H and ORF474 of the prolate-head phage JCL1032 is implicated in specificity of adsorption of phage to its host, Lactobacillus delbrueckii. J Bacteriol 2002;184(9):2455-2459.

42. Uchiyama J, Takemura I, Satoh M, et al. Improved adsorption of an Enterococcus faecalis bacteriophage PhiEF24C with a spontaneous point mutation. PLoS One 2011;6(10):e26648. doi: 26610.21371/journal.pone.0026648. Epub 0022011 Oct 0026625.

43. Nguyen HM, Kang C. Lysis Delay and Burst Shrinkage of Coliphage T7 by Deletion of Terminator T $\phi$ Reversed by Deletion of Early Genes. J Virol 2014;88(4):2107-2115. doi: 2110.1128/JVI.03274-03213. Epub 02013 Dec 03211.

44. Bondy-Denomy J, Pawluk A, Maxwell KL, et al. Bacteriophage genes that inactivate the CRISPR/Cas bacterial immune system. Nature 2013;493(7432):429-432. doi: 410.1038/nature11723. Epub 12012 Dec 11716.

45. Seed KD, Lazinski DW, Calderwood SB, et al. A bacteriophage encodes its own CRISPR/Cas adaptive response to evade host innate immunity. Nature 2013;494(7438):489-491. doi: 410.1038/nature11927.

46. Sauve C, Azoulay-Dupuis E, Moine $P$, et al. Efficacies of cefotaxime and ceftriaxone in a mouse model of pneumonia induced by two penicillin- and cephalosporin-resistant strains of Streptococcus pneumoniae. Antimicrob Agents Chemother 1996;40(12):2829-2834.

47. Dominguez-Herrera J, Velasco C, Docobo-Perez F, et al. Impact of qnrA1, qnrB1 and qnrS1 on the efficacy of ciprofloxacin and levofloxacin in an experimental pneumonia model caused by 
Escherichia coli with or without the GyrA mutation Ser83Leu. J Antimicrob Chemother 2013;68(7):1609-1615.

48. Docobo-Perez F, Nordmann P, Dominguez-Herrera J, et al. Efficacies of colistin and tigecycline in mice with experimental pneumonia due to NDM-1-producing strains of Klebsiella pneumoniae and Escherichia coli. Int J Antimicrob Agents 2012;39(3):251-254.

49. Knudsen JD, Fuursted K, Frimodt-Moller N, et al. Comparison of the effect of cefepime with four cephalosporins against pneumococci with various susceptibilities to penicillin, in vitro and in the mouse peritonitis model. J Antimicrob Chemother 1997;40(5):679-686.

50. Chan BK, Abedon ST. Phage therapy pharmacology phage cocktails. Adv Appl Microbiol 2012;78:1-23.(doi):10.1016/B1978-1010-1012-394805-394802.300001-394804.

51. Craven DE, Steger KA. Epidemiology of nosocomial pneumonia. New perspectives on an old disease. Chest 1995;108(2 Suppl):1S-16S.

52. Letarov A, Kulikov $\mathrm{E}$. The bacteriophages in human- and animal body-associated microbial communities. J Appl Microbiol 2009;107(1):1-13. doi: 10.1111/j.1365-2672.2009.04143.x. Epub 02009 Feb 04123.

53. Mendez J, Audicana A, Cancer M, et al. Assessment of drinking water quality using indicator bacteria and bacteriophages. J Water Health 2004;2(3):201-214.

54. Miernikiewicz P, Dabrowska K, Piotrowicz A, et al. T4 phage and its head surface proteins do not stimulate inflammatory mediator production. PLoS One 2013;8(8):e71036. doi: 71010.71371/journal.pone.0071036. eCollection 0072013.

55. Dabrowska K, Miernikiewicz P, Piotrowicz A, et al. Immunogenicity studies of proteins forming the t4 phage head surface. J Virol 2014;88(21):12551-12557. doi: 12510.11128/JVI.0204312514. Epub 12014 Aug 12520.

56. Loc-Carrillo C, Abedon ST. Pros and cons of phage therapy. Bacteriophage 2011;1(2):111-114. 57. Abedon ST, Kuhl SJ, Blasdel BG, et al. Phage treatment of human infections. Bacteriophage 2011;1(2):66-85.

58. Morello E, Saussereau E, Maura D, et al. Pulmonary bacteriophage therapy on Pseudomonas aeruginosa cystic fibrosis strains: first steps towards treatment and prevention. PLoS One 2011;6(2):e16963.

59. Alemayehu D, Casey PG, McAuliffe O, et al. Bacteriophages phiMR299-2 and phiNH-4 can eliminate Pseudomonas aeruginosa in the murine lung and on cystic fibrosis lung airway cells. MBio 2012;3(2):e00029-00012. 


\section{Figures and Legends}

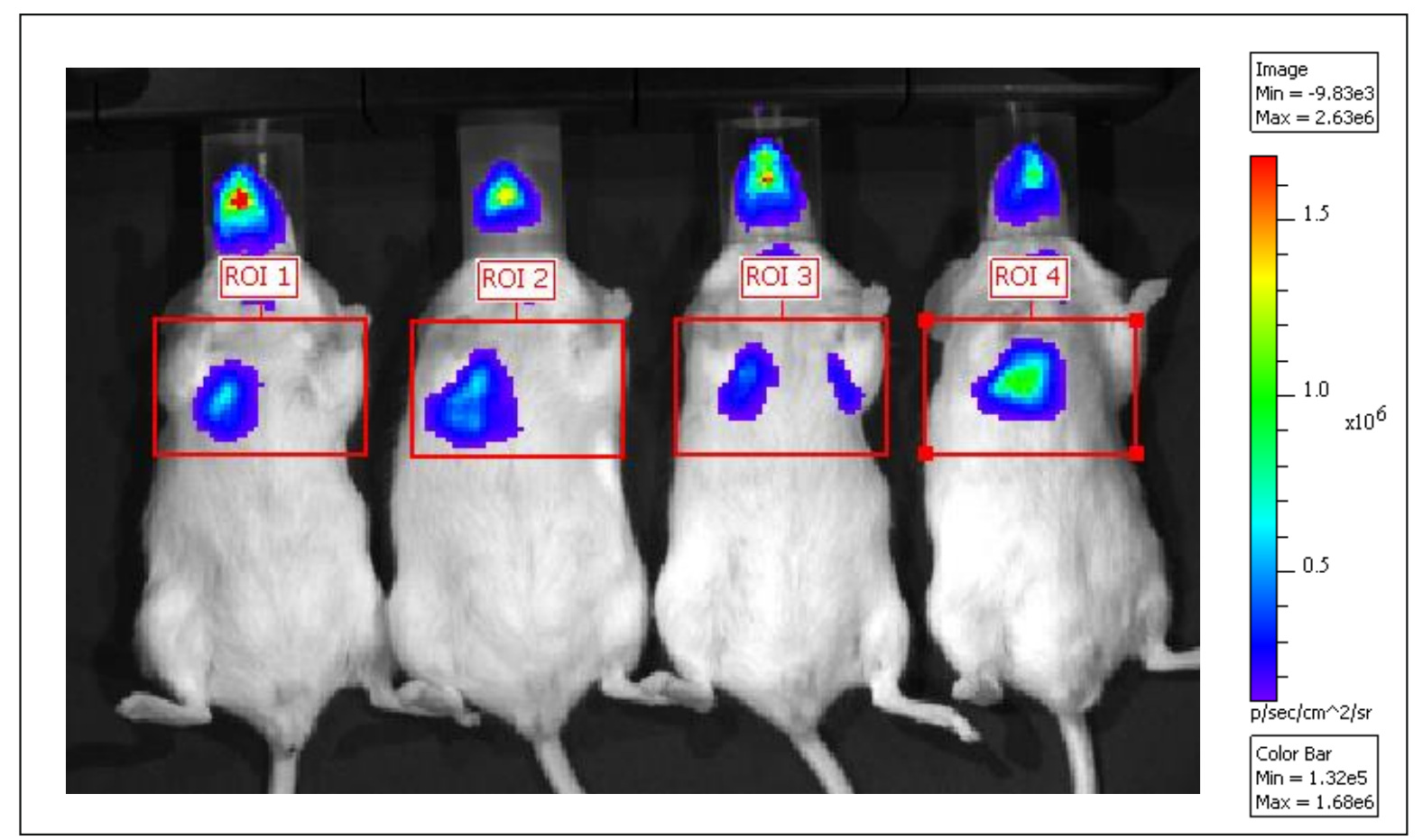

Figure 1: Typical acquisition of bioluminescence imaging.

This picture represents a typical color-coded bioluminescence signal merged with classical photography. Four mice infected with strain 536-lux are shown, 4 hours after infection without treatment. Red rectangles represent regions of interest (ROI) of the chest area used for light quantification. 

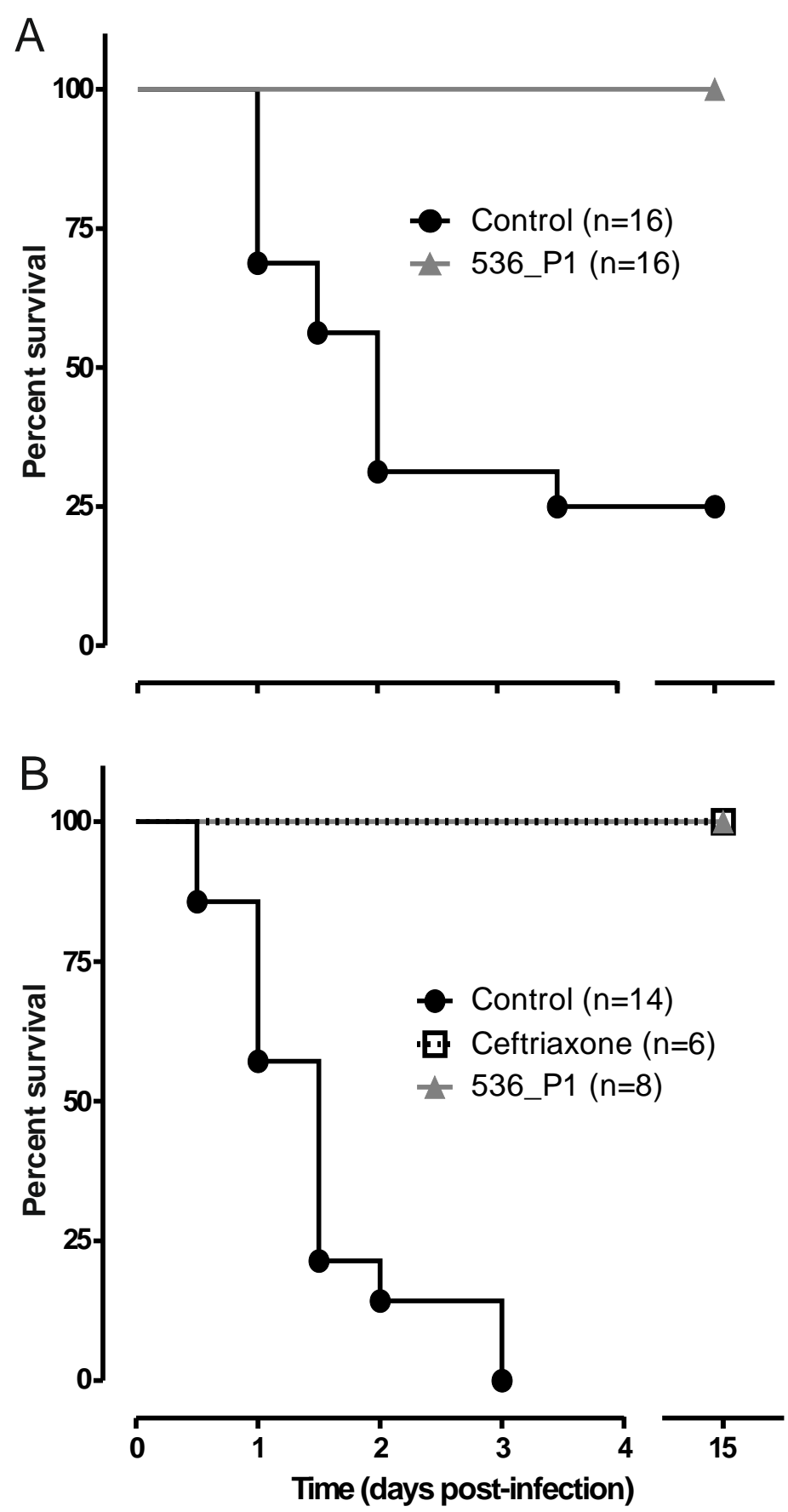

Figure 2: Effect of bacteriophage treatment on survival of $E$. coli infected mice

(A): Survival of mice infected with $1 \times 10^{7}$ CFU of strain $536-\mathrm{lux}(n=32)$ and treated with bacteriophage 536_P1 ( $n=16$, grey line and triangle) at a multiplicity of infection of $0.3(n=8)$ or $3(n=8)$. Control mice ( $n=16$, black line and dots) received PBS. (B): Survival of mice infected with $4 \times 10^{7}$ CFU of strain 536$\operatorname{lux}(n=28)$ and treated with either bacteriophage 536_P1 at a multiplicity of infection of 3 ( $n=8$, grey line and triangle) or ceftriaxone $(n=6$, dotted line and square). Control mice ( $n=14$, black line and dots) received normal saline intraperitoneally and either intranasal PBS $(n=10)$ or heat-inactivated 536_P1 ( $n=4)$. 


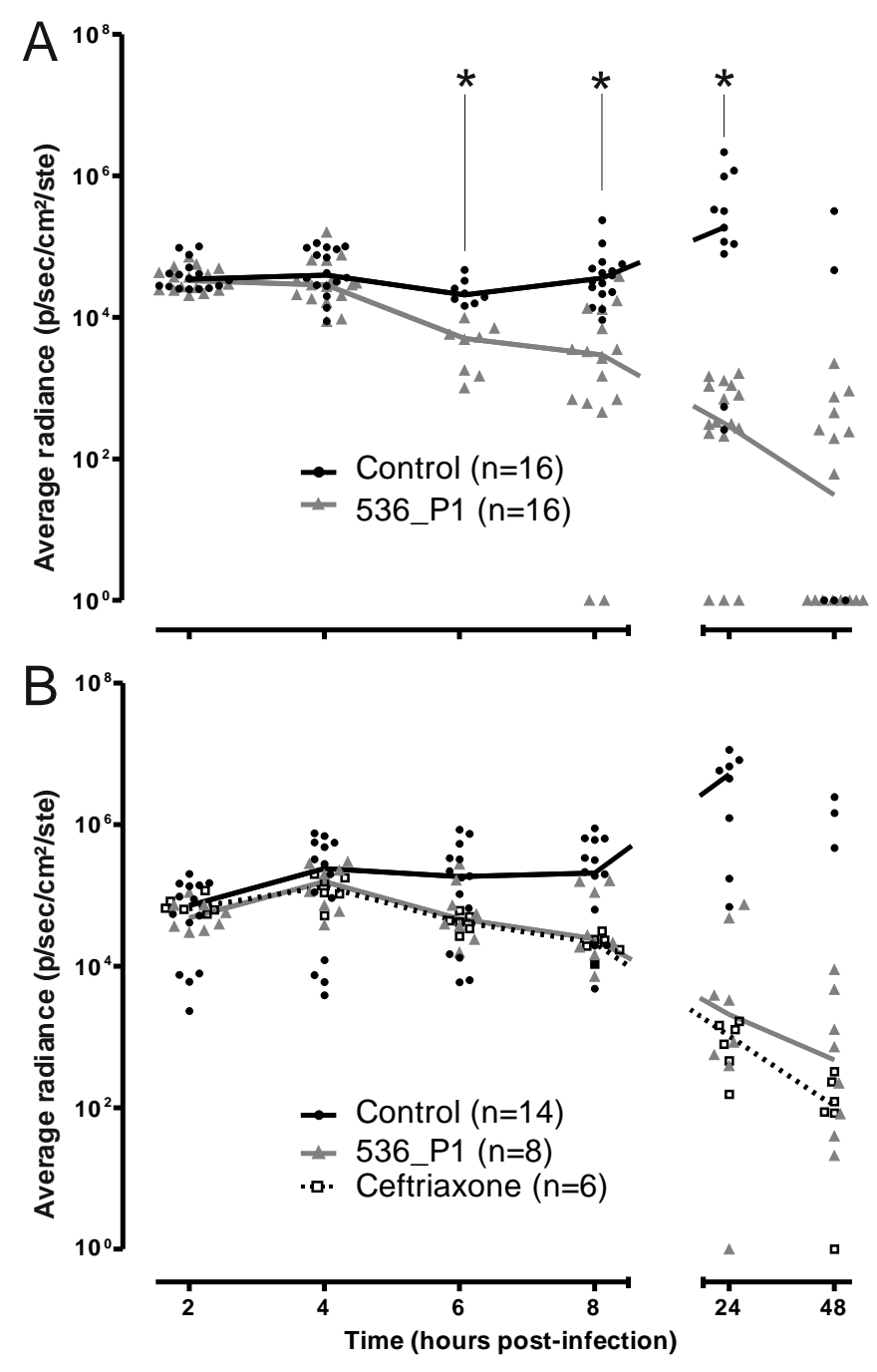

Figure 3: Light quantification emitted over time from the chest area of infected mice

(A): Light emitted from mice infected with $1 \times 10^{7}$ CFU of strain 536-lux ( $\left.n=32\right)$ and treated with bacteriophage 536_P1 ( $n=16$, grey line and triangles) at a multiplicity of infection of $0.3(n=8)$ or 3 $(n=8)$. Control mice $\left(n=16\right.$, black line and dots) received PBS. ${ }^{*}: p<0.05$ between the two groups. NB: due to a temporary anesthetic system failure during one of the two independent experiments, the number of points recorded at 6 hours after infection is reduced. (B): Light emitted from mice infected with $4 \times 10^{7}$ CFU of strain 536-lux ( $\left.n=28\right)$ treated with either bacteriophage 536_P1 at a MOI of $3(n=8$, grey line and triangles) or ceftriaxone ( $n=6$, dotted lines and squares). Control mice ( $n=14$, black line and dots) received normal saline intraperitoneally and either intranasal PBS ( $n=10)$ or heat inactivated 536_P1 $(n=4)$.

For panels $A$ and $B$, each point (dots, square and triangles) represents the amount of light emitted from individual mice in logarithmic(10) unit. Median value for each group is represented by a line (the latter is not shown for control group at 48 hours post-infection as the number of surviving mice was too small to be representative). 


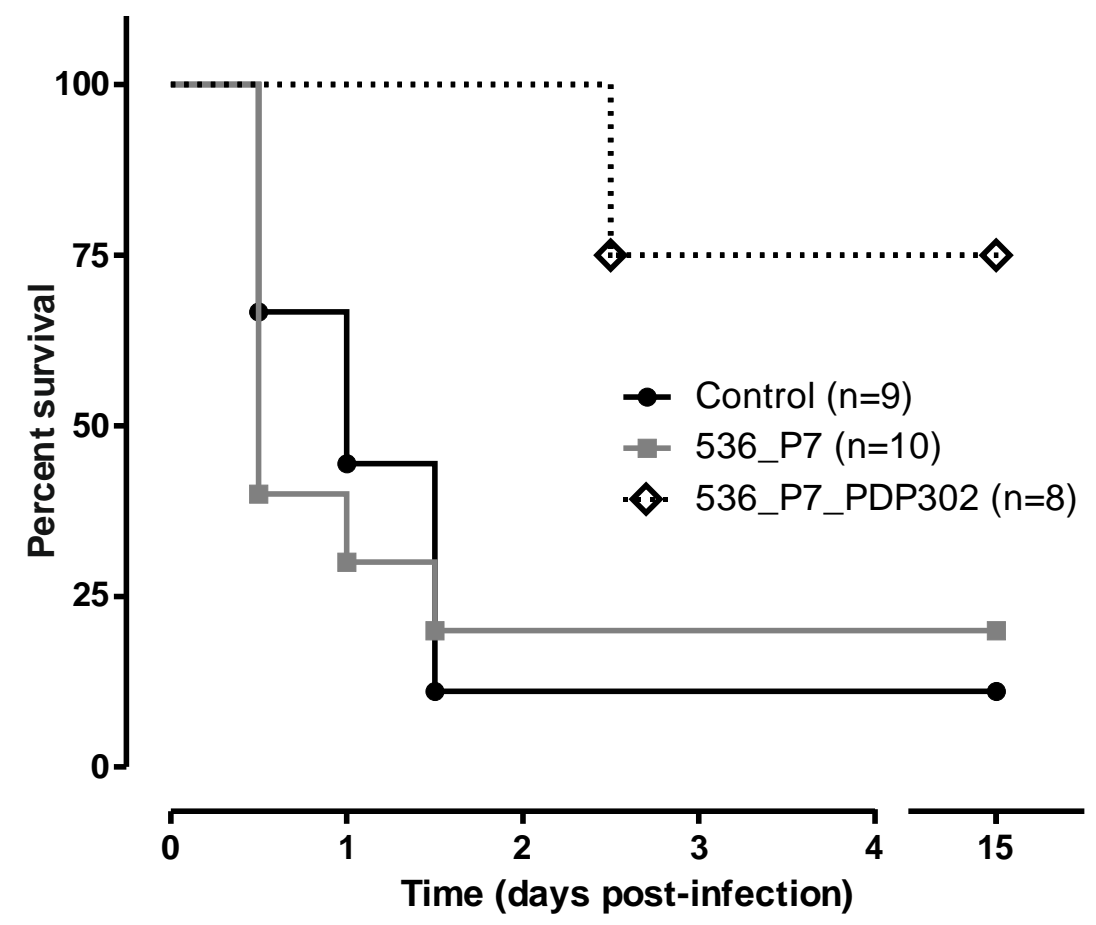

Figure 4: Bacteriophage adaptation improves mice survival

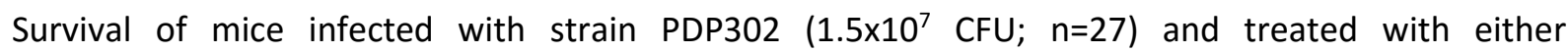
bacteriophage 536_P7 ( $n=10$, grey line and squares) or bacteriophage 536_P7_PDP302 ( $n=8$, black dotted line and diamonds), both at $\mathrm{MOI}$ of 10 . Control mice $(n=9)$ received PBS (black line and dots). 


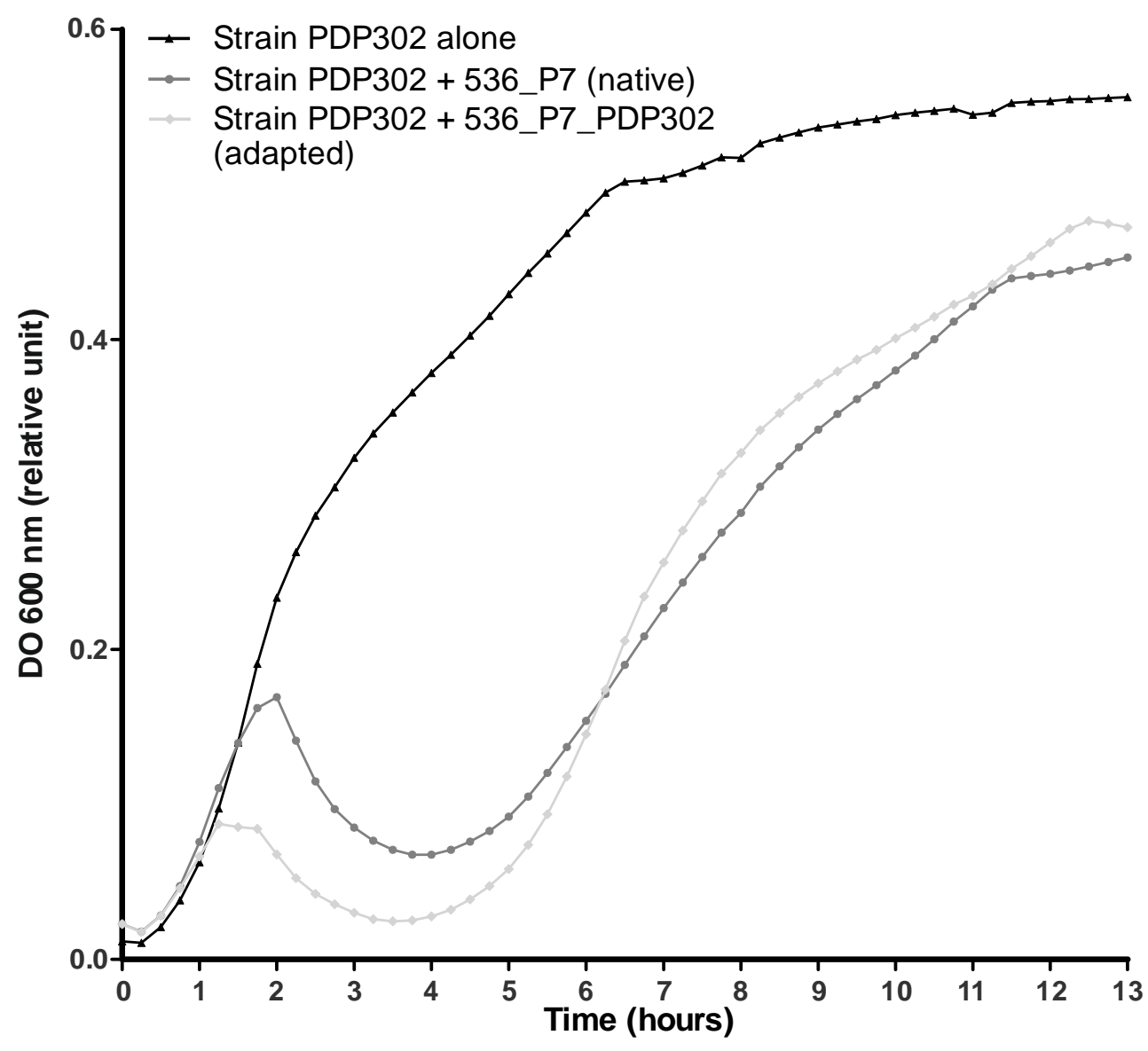

Figure 5: In vitro lysis kinetics of native and adapted bacteriophages on clinical strain PDP302

Strain PDP302 was incubated at $37^{\circ} \mathrm{C}$ in LB broth without (triangles) or with bacteriophages at $\mathrm{MOI}$ of 0.01 (536_P7, black dots; 536_P7_PDP302, diamonds) and OD $600 \mathrm{~nm}$ was recorded during 12 hours. 
Table 1: Bacterial and bacteriophage counts on lung homogenates and data obtained from bronchoalveolar lavage fluids

\begin{tabular}{|c|c|c|c|c|c|c|}
\hline & \multirow{2}{*}{$\begin{array}{l}\text { Uninfected } \\
\text { animals }\end{array}$} & \multirow{2}{*}{$\begin{array}{l}\text { hours post- } \\
\text { infection } \\
\text { (without } \\
\text { treatment) }\end{array}$} & \multicolumn{2}{|c|}{ r 6 hours post-infection 7} & \multicolumn{2}{|c|}{ 「 16 hours post-infection 7} \\
\hline & & & PBS (control) & $\begin{array}{c}\text { 536_P1 } \\
\text { (treatment) }\end{array}$ & PBS (control) & $\begin{array}{c}\text { 536_P1 } \\
\text { (treatment) }\end{array}$ \\
\hline $\begin{array}{l}\text { Bacterial count (lung } \\
\text { homogenate, cfu/g) }\end{array}$ & N.A. & $\begin{array}{c}1.0 \times 10^{8} \\
{\left[4.5 \times 10^{7}\right.} \\
\left.1.6 \times 10^{8}\right]\end{array}$ & $\begin{array}{c}8.3 \times 10^{6} \\
{\left[5.2 \times 10^{6} ;\right.} \\
\left.1.0 \times 10^{7}\right]\end{array}$ & $\begin{array}{c}4.3 \times 10^{5} \\
{\left[2.0 \times 10^{5}\right.} \\
\left.1.3 \times 10^{6}\right]^{*}\end{array}$ & $\begin{array}{c}4.8 \times 10^{8} \\
{\left[2.1 \times 10^{8}\right.} \\
\left.5.5 \times 10^{8}\right]\end{array}$ & $\begin{array}{c}2.4 \times 10^{6} \\
{\left[2.1 \times 10^{5}\right.} \\
\left.1.8 \times 10^{7}\right]\end{array}$ \\
\hline $\begin{array}{l}\text { Bacteriophage count (lung } \\
\text { homogenate, pfu/g) }\end{array}$ & N.A. & N.A. & 0 & $\begin{array}{c}8.8 \times 10^{8} \\
{\left[2.6 \times 10^{8}\right.} \\
\left.1.4 \times 10^{9}\right]\end{array}$ & 0 & $\begin{array}{c}1.1 \times 10^{10} \\
{\left[2.5 \times 10^{9} ;\right.} \\
\left.1.5 \times 10^{10}\right] \S\end{array}$ \\
\hline \multicolumn{7}{|l|}{$\begin{array}{l}\text { Broncho-alveolar lavage } \\
\text { fluid analysis }\end{array}$} \\
\hline $\begin{array}{r}\text { Total nucleated cell count } \\
(\text { cells } / \mathrm{mL})\end{array}$ & $\begin{array}{r}1.3 \times 10^{6} \\
\pm 2.3 \times 10^{5} \\
\end{array}$ & N.A. & $\begin{array}{c}3.1 \times 10^{6} \\
\left( \pm 9.7 \times 10^{5}\right)\end{array}$ & $\begin{array}{c}3.9 \times 10^{6} \\
\left( \pm 9.4 \times 10^{5}\right) \\
\end{array}$ & $\begin{array}{c}1.0 \times 10^{7} \\
\left( \pm 2.3 \times 10^{6}\right)\end{array}$ & $\begin{array}{c}1.0 \times 10^{7} \\
\left( \pm 4.5 \times 10^{6}\right) \S \\
\end{array}$ \\
\hline Ratio of PMN/MM (\%) & $\begin{array}{l}4.2 / 95.8 \\
( \pm 1.5)\end{array}$ & N.A. & $\begin{array}{c}93.2 / 6.8 \\
( \pm 2.7)\end{array}$ & $\begin{array}{c}92.2 / 7.8 \\
( \pm 4.2)\end{array}$ & $\begin{array}{c}96.8 / 3.2 \\
( \pm 1.8)\end{array}$ & $\begin{array}{c}91.8 / 8.2 \\
( \pm 4.8)^{*}\end{array}$ \\
\hline $\begin{array}{l}\text { Percentage of phagocytes } \\
\text { with engulfed bacteria (\%) }\end{array}$ & N.A. & N.A. & N.A & N.A & $26.6( \pm 6.8)$ & $0.6( \pm .0 .2) *$ \\
\hline Total protein $(\mu \mathrm{g} / \mathrm{mL})$ & $74( \pm 6)$ & N.A. & $140( \pm 59)$ & $208( \pm 44)$ & $320( \pm 62)$ & $304( \pm 76) \S$ \\
\hline $\begin{array}{r}\text { LDH activity (fold change } \\
\text { compared to non-infected } \\
\text { condition) }\end{array}$ & 1 & N.A. & $1.3( \pm 0.3)$ & $1.3( \pm 0.2)$ & $3.9( \pm 0.7)$ & $3.1( \pm 0.6) \S$ \\
\hline$K C / C X C L-1(p g / m L)$ & $24( \pm 12)$ & N.A. & $\begin{array}{c}14816 \\
( \pm 3720)\end{array}$ & $\begin{array}{c}17729 \\
( \pm 2531)\end{array}$ & $\begin{array}{l}14927 \\
( \pm 1044)\end{array}$ & $\begin{array}{c}3487( \pm 1264) \\
*\end{array}$ \\
\hline \multicolumn{7}{|c|}{$\begin{array}{l}\text { *: } p<0.05 \text { for intergroup comparison at the same time point, } \S: p<0.05 \text { when comparing both control and treated group at time } 6 \text { vs } \\
16 \text { hours post-infection, N.A: not applicable or not assessed, cfu: colony-forming unit, pfu: plaque-forming unit, PBS: phosphate- } \\
\text { buffered saline, PMN: polymorphonuclears, MM: monocyte-macrophages. Data displayed are median [25th ; } 75 \text { th percentile] or } \\
\text { mean ( } \pm \text { standard deviation). Four mice per condition and per time point. Infection with } 1.10 \times 10^{7} \mathrm{cfu} \text { of } 536 \text {, treatment with } 536 \_ \text {P1 } \\
\text { (multiplicity of infection of 10). }\end{array}$} \\
\hline
\end{tabular}




\section{Supplemental Digital Content}

Linked to manuscript entitled "Treatment of highly virulent extra-intestinal pathogenic Escherichia coli pneumonia with bacteriophages" by Dufour et al.

\section{1- Stability of pCM17 plasmid in strain 536-lux without antibiotic pressure}

Stability of the plasmid was tested by successive seeding of the strain in liquid antibiotic-free medium, renewed twice a day during 11 days. All cultures were performed at $37^{\circ} \mathrm{C}$ with continuous shaking ( $200 \mathrm{rpm}$ ). Each 12 hours, $20 \mu \mathrm{L}$ of the culture were diluted into $100 \mathrm{~mL}$ of fresh medium. Control cultures contained kanamycin $(25 \mu \mathrm{g} / \mathrm{mL})$.

Plasmid loss was evaluated by analyzing the plasmid linked phenotype (ability of the strain to produce light), twice a day during the 4 first days and thereafter once from day 6.5 to 10.5 . Analysis of luminescence was performed both on liquid medium and solid agar plate.

a- Luminescence quantification of liquid culture

After 12 hours of growth, cultures (with and without kanamycin) were diluted in fresh LB broth to approximately an $\mathrm{OD}_{600 \mathrm{~nm}}$ of 0.3 . Then, $6 \mathrm{~mL}$ of each culture were poured in an empty Petri dish and immediately introduced in the luminescence imaging system (Ivis Spectrum, Xenogen) for data recording (exposure time $0.5 \mathrm{sec}$ ). Luminescence was quantified by determining a region of interest (fixed circular surface covering the Petri dish) and then normalized with the previously measured optical density.

Results: as shown on the Figure S1, the normalized amount of luminescence remained stable during the first 7 days and then decreased quickly.

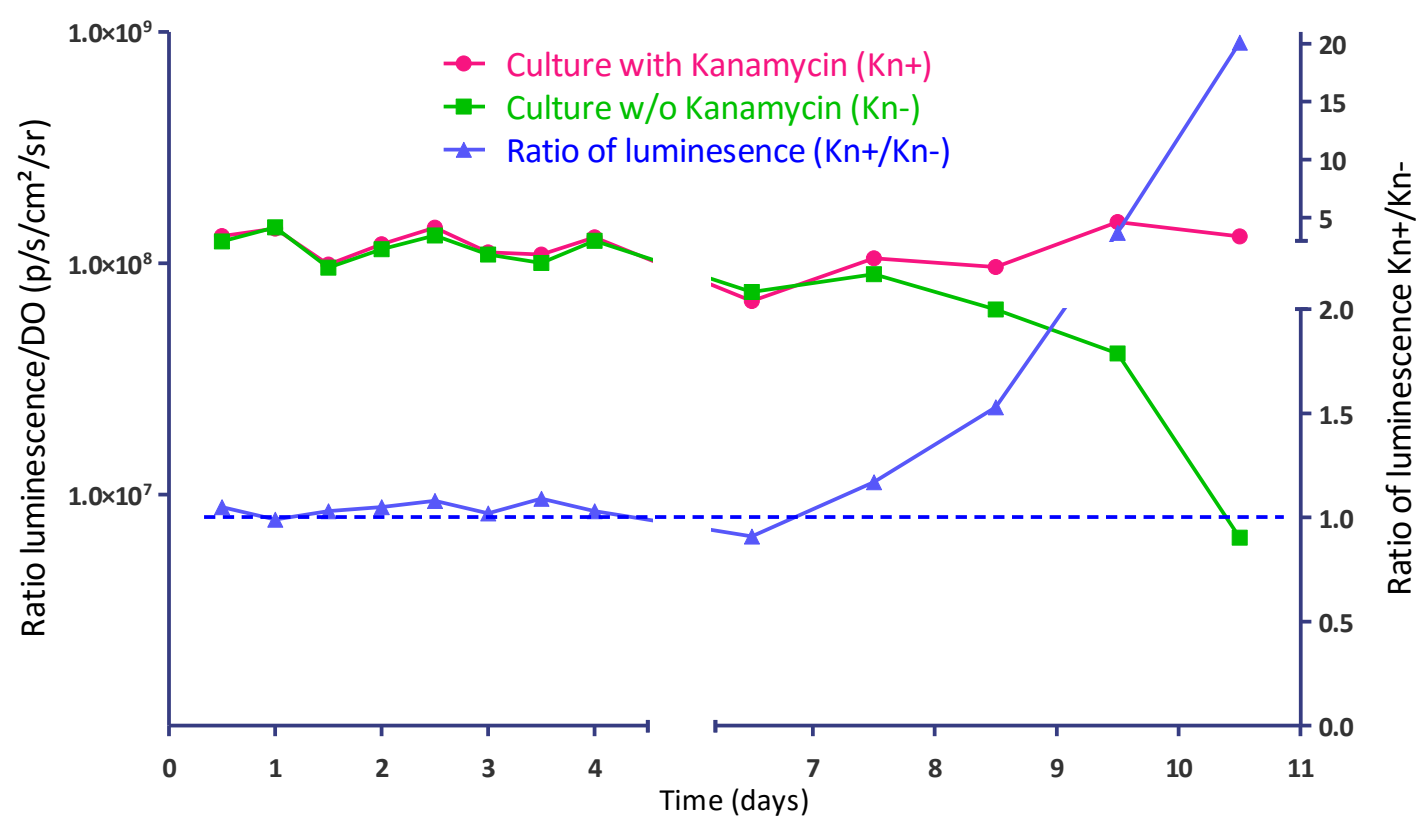

Figure S1. Evolution of amount of light in normalized condition produced by liquid 536lux strain cultured with or without kanamycin according to time. The left ordinate axis 
represents the normalized luminescence flow recorded and the right ordinate axis the ratio of this signal in both conditions.

b- Luminescence phenotype on agar plates

From the above diluted culture, an additional dilution ( $10^{5}$ fold) was performed and $40 \mu \mathrm{L}$ were spread on agar plates ( 3 replicates) with and without kanamycin. After approximately 12 hours incubation, luminescence was acquired using the same device and percentage of colony displaying a luminescent phenotype was calculated.

Results: as shown on Figure S2 below, in absence of kanamycin $100 \%$ of colonies expressed the luminescent phenotype until day 7 followed by a quick loss of the light emitting phenotype, while in presence of kanamycin $100 \%$ of colonies kept this phenotype.

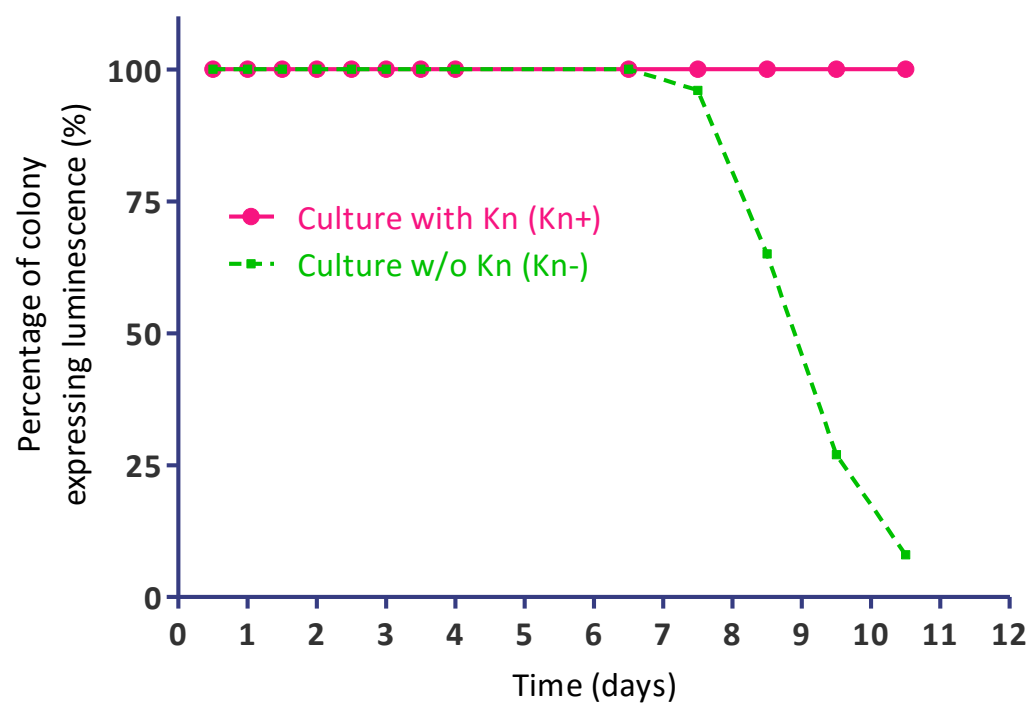

Figure S2. Percentage of colony expressing luminescence according to time and antibiotic pressure

We then concluded that the plasmid was stable in absence of antibiotic pressure for a period of 7 days.

\section{2- Efficiency of plaquing (EOP) and plaque-forming unit (PFU)}

Titration of bacteriophage was performed by dropping off a known volume of a tenfold serially diluted solution, in triplicate, on an agar plate previously overlaid with the bacteria to test. After incubation, the area where bacteriophages were spotted is either clear (full lysis obtained by a large number of bacteriophages) or displayed individual plaques (the number of these plaques represent the amount of bacteriophages) or do not affect the bacterial lawn (absence of bacteriophages).

To determine the efficiency of plaquing (EOP) of a given bacteriophage on a non-host strain, the same bacteriophage solution was spotted both on the host strain and the non-host strain. The 
EOP is defined by the ratio of the titer obtained on the non-host strain to the titer obtained on the host strain.

Below is shown an example of bacteriophage 536_P1 and 536_P7 tested on two hosts (E. coli 536 and E. coli PDP302). Each bacteriophage solution was serially diluted $\left(10^{-1}\right.$ to $\left.10^{-7}\right)$ and $4 \mu \mathrm{L}$ of each dilution were spotted in triplicate on agar plates formerly covered by strains 536 or PDP302. By counting individual plaques formed by 536_P1 on strain 536 we calculated its titer to $4.6 \times 10^{8}$ $\mathrm{PFU} / \mathrm{mL}$ while it was $3.7 \times 10^{7} \mathrm{PFU} / \mathrm{mL}$ on strain PDP302 leading us to calculate an EOP value of 0.08 .

Conversely the titer of 536_P7 was $9.1 \times 10^{9} \mathrm{PFU} / \mathrm{mL}$ on both 536 and PDP strains leading us to calculate an EOP value of 1. Bacteriophage 536_P1_PDP302 displays also an EOP of 1 on both 536 and PDP302 strains (not shown).
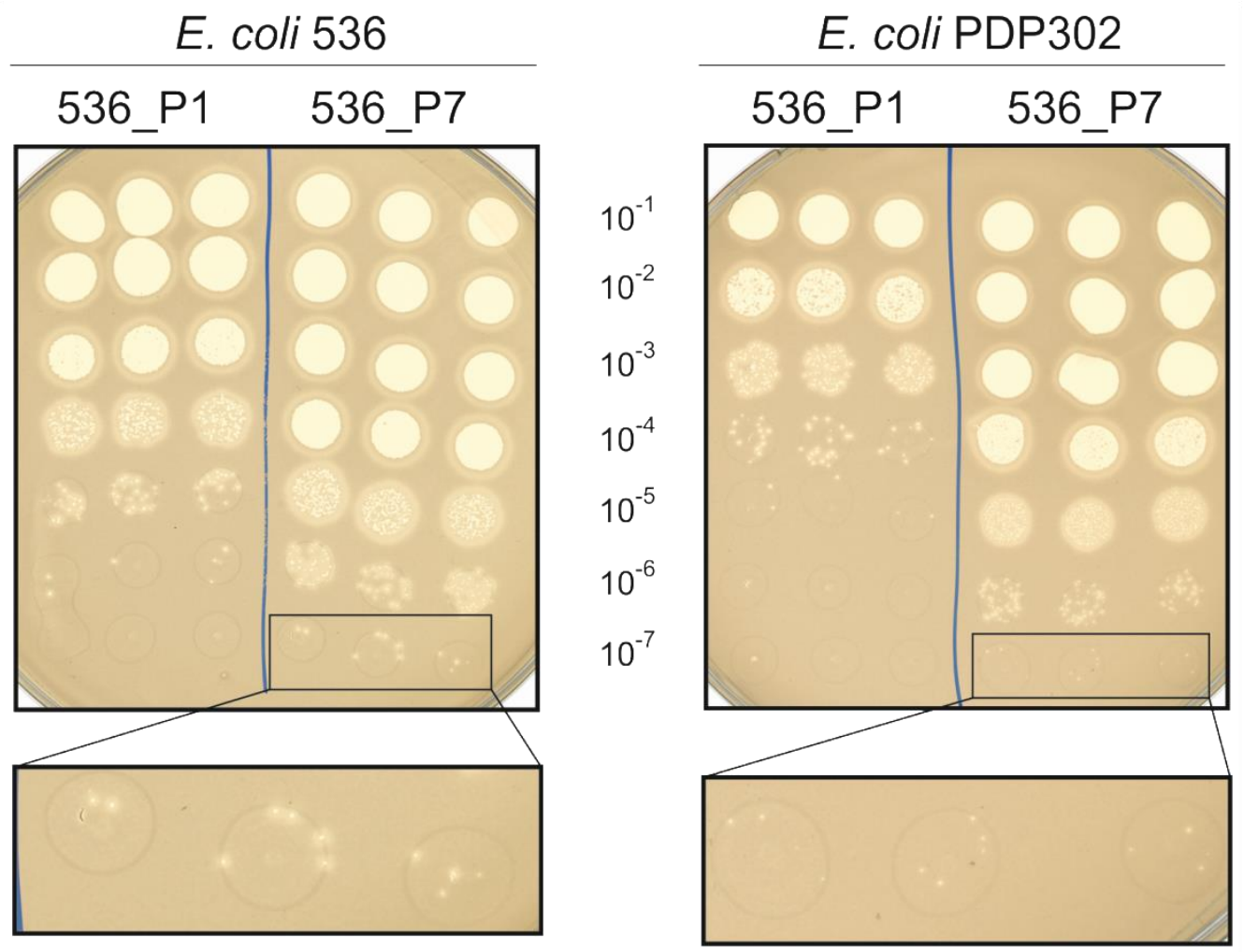

\section{3- Lysis kinetics of 536_P7 and 536_P7_PDP302 bacteriophages on strain PDP302}

Lysis kinetic of the PDP302 strain were performed as described previously (Maura et al., Environ Microbiol, 2012) using 96 well plate at multiplicity of infection (MOI) of 0.01 . Strain PDP302 without bacteriophage was used as control. All conditions were performed in quadruplicates and the experiment was repeated four times independently.

Both solutions of bacteriophages 536_P7 and 536_P7_PDP302 were prepared at the same concentration which was checked by titration in triplicate. For these four independent 
experiments, mean difference \pm SD in bacteriophages concentrations (536_P7 - 536_P7_PDP302) was $0.06 \pm 0.17$ ( $\log _{10}$ unit) and mean absolute difference was $0.11 \pm 0.13$.

Only one representative curve at $\mathrm{MOI} 0.01$ is shown in the manuscript.

\section{4- Transmission electron microscopy of bacteriophages}

Both 536_P1 (left) and 536_P7 (right) display an icosahedric head and a contractile tail, a classical morphology for members of the Myoviridae family of the Caudovirales order of viruses. Scale bar represent $100 \mathrm{~nm}$.
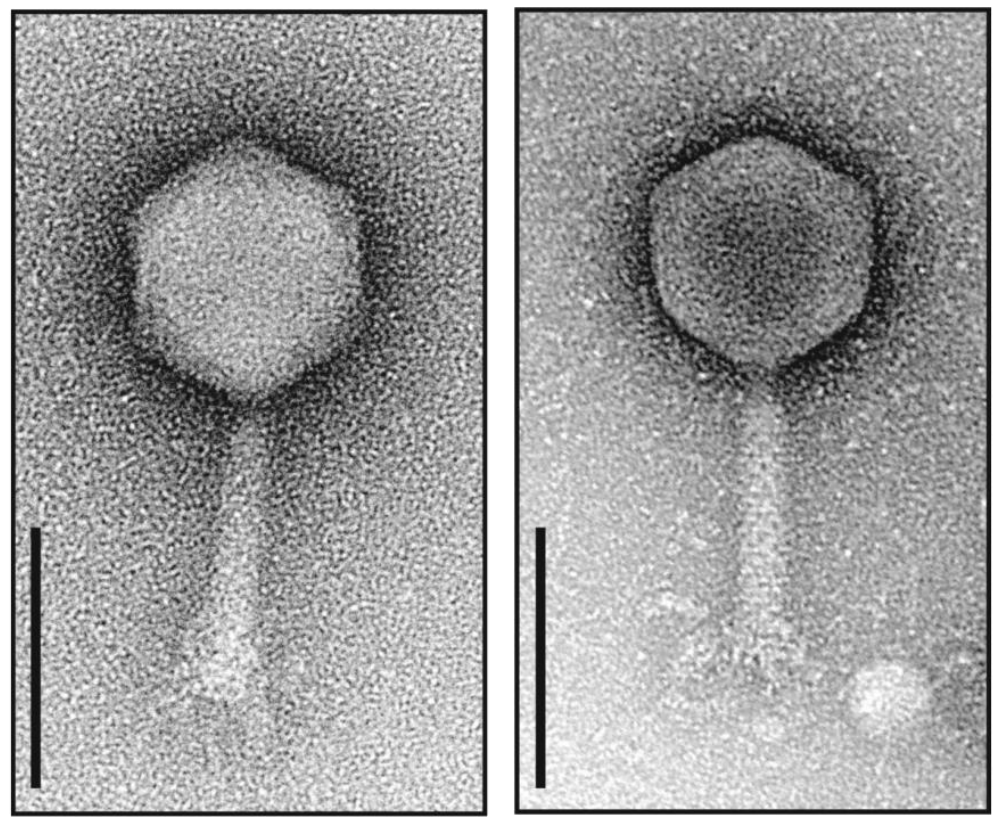

5- Bronchoalveolar lavage (BAL) procedure and BAL fluids processing for cytological and biochemical analysis

BALs were performed on euthanized mice using a $18 \mathrm{G}$ flexible polyurethane catheter (Insyte Autoguard BC, BD Bioscience, USA) inserted in the upper part of the trachea after a small incision on its anterior face. Cold PBS $(4 \times 0.5 \mathrm{~mL})$, supplemented with protease inhibitor (Complete protease inhibitor tablets, Roche, Switzerland) was used to wash the lungs.

Volume of retrieved BAL fluids was similar for the 20 mice $(1.7 \pm 0.06 \mathrm{~mL})$.

Samples were centrifuged $\left(700 \mathrm{G}, 10^{\prime}, 4^{\circ} \mathrm{C}\right)$ and supernatants were kept for biochemical analysis. Pellets were resuspended in a selective lysis buffer to remove red blood cells (ACK lysing buffer, Lonza, Switzerland) and then washed twice in PBS. Total nucleated cells were counted using a cell counter (Cellometer K2, Nexcelom, USA). Cytological examination was performed using a Cytospin device and stained (May-Grunwald-Giemsa). Differential cell count was performed based on at least 500 cells. Proportion of phagocytes with intracellular bacteria was determined as the ratio of cells (polymorphonuclears and monocyte-macrophages) containing one or more bacteria in their cytoplasm to the total number of cells. 
Quantitative analysis (in duplicate or triplicate) of total protein, LDH activity and KC cytokine in BAL fluid was performed using respectively a Bradford method (Quick Start Protein Assay, Biorad, USA), the CytoTox96 non-radioactive assay (Promega, USA) and an ELISA technique (DuoSet Mouse KC, R\&D system, USA) according to the manufacturer's instructions.

\section{6- Weight evolution of mice infected with 536-lux}

Mice were weighted at least daily until day 3 post-infection. No difference was observed between groups. In mice infected with $1 \times 10^{7} \mathrm{cfu}$, mean weight was identical at day 2 and day 3 post-infection ( $22.8 \pm 0.9$ and $22.7 \pm 1.1$ grams respectively). At day 3 , weight loss was significantly higher in mice infected with $4 \times 10^{7}$ cfu compared to mice infected with $1 \times 10^{7}$ (respectively -12.0 $\pm 4.8 \%$ and $-18.5 \pm 0.8 \%, p<0.001$ ), without nevertheless compromising survival (figure S3 and S4). Below are provided weights the infection day (D0) and 7 days after (D7).

\begin{tabular}{|c|c|c|c|c|}
\hline & \multicolumn{2}{|c|}{$1 \times 10^{7} \mathrm{cfu}$} & \multicolumn{2}{|c|}{$4 \times 10^{7} \mathrm{cfu}$} \\
\hline & Do & D7 & DO & D7 \\
\hline Control & $25.8 \pm 0.9$ & $24.9 \pm 0.6$ & $24.8 \pm 1.4$ & no survivor \\
\hline 536_P1 & $25.9 \pm 0.7$ & $25.1 \pm 0.6$ & $25.7 \pm 0.9$ & $24.6 \pm 0.9$ \\
\hline Ceftriaxone & - & - & $25.6 \pm 1.3$ & $24.3 \pm 1.1$ \\
\hline
\end{tabular}

Table 1: Mean weights (gram) of each group the infection day (D0) and 7 days after (D7).

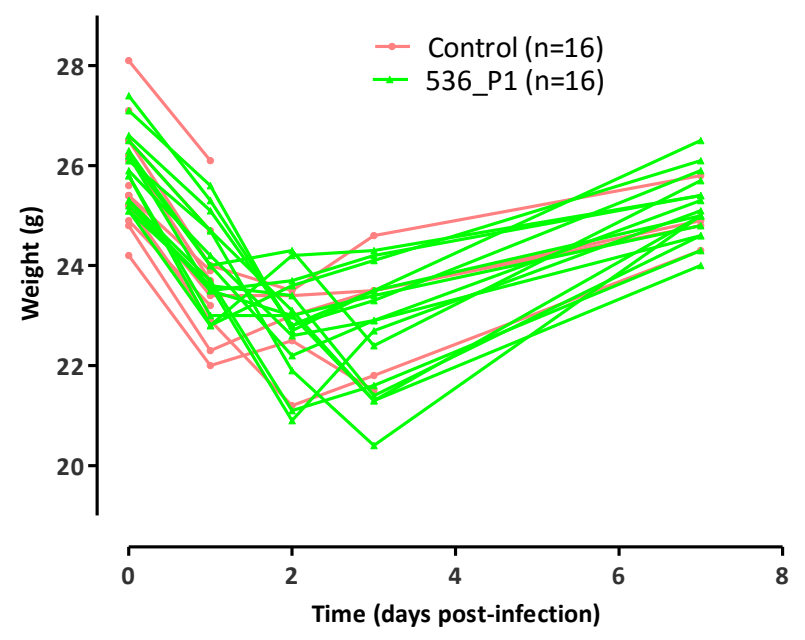

Figure S3. Weight evolution of mice infected with $1 \times 10^{7} \mathrm{CFU}$ of 536 -lux

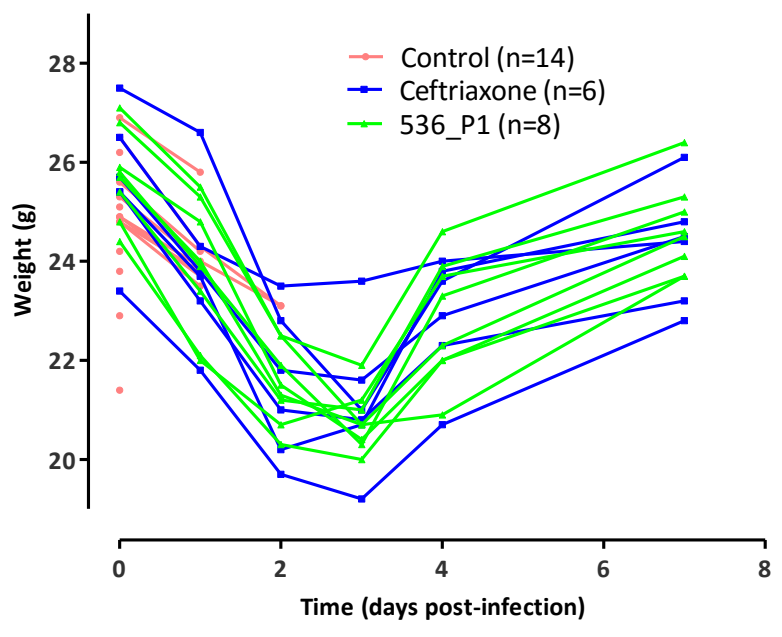

Figure S4. Weight evolution of mice infected with $4 \times 10^{7}$ CFU of 536-lux

\section{7- Cytological observations of bronchoalveolar lavage fluids (BALF)}


Below are shown typical observations of the cells present in the BALF of 4 infected mice, 16 hours post-infection. Photographs $A+B$ represent 2 untreated mice (control mice) and $C+D$ represent 2 treated mice (536_P1). Observations made under 100x magnification, after MayGrunwald-Giemsa staining.

While phagocytic cells in untreated mice $(A+B)$ display a high number of engulfed bacteria, cells retrieved from phage treated mice $(C+D)$ present scarce image of engulfed bacteria. When these figures are present (D), bacteria never exhibit a rode-shaped aspect but rather a dot-shaped one, which is compatible with an end-stage lysis (that is the absence of freshly engulfed bacteria).
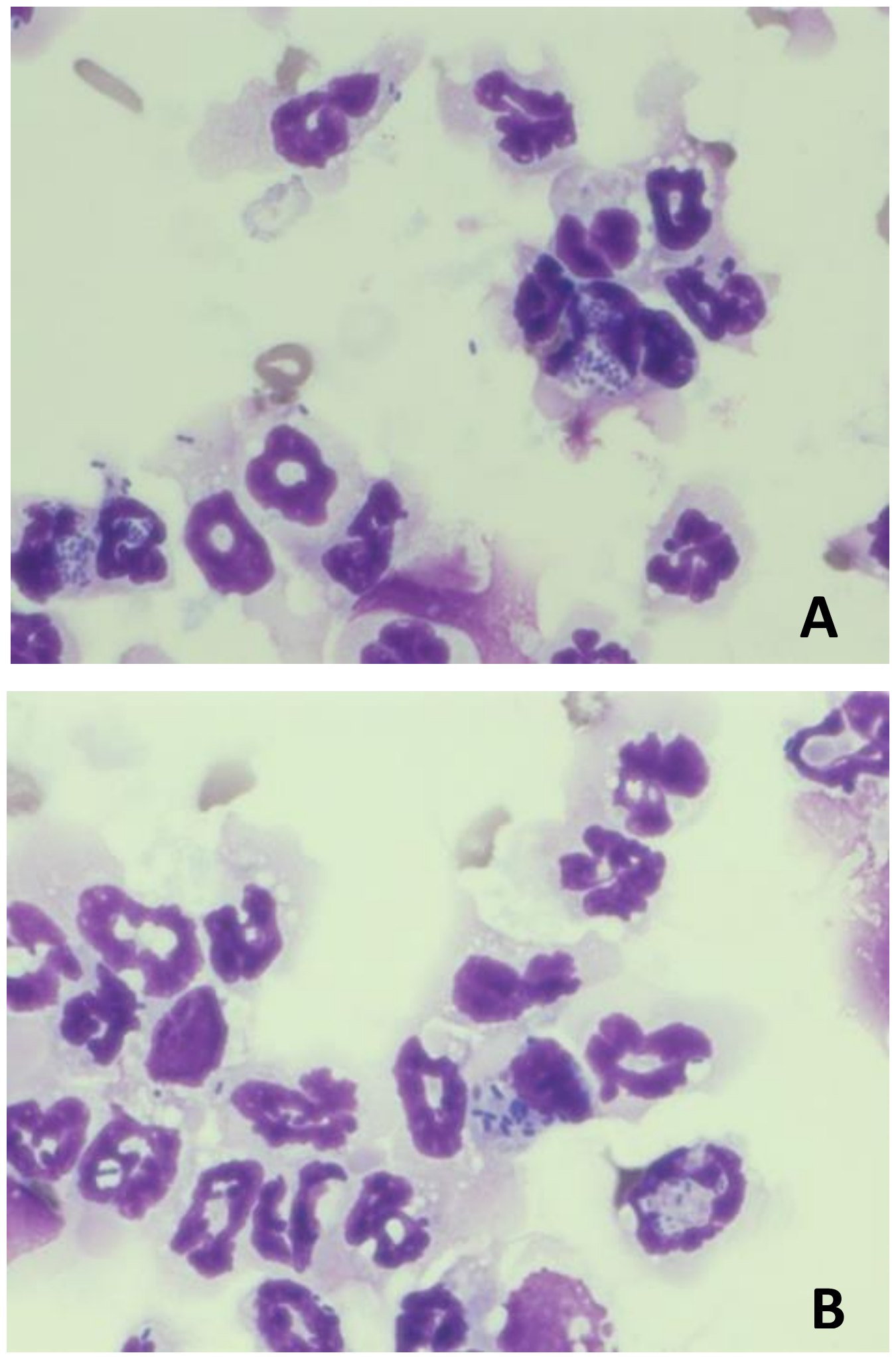

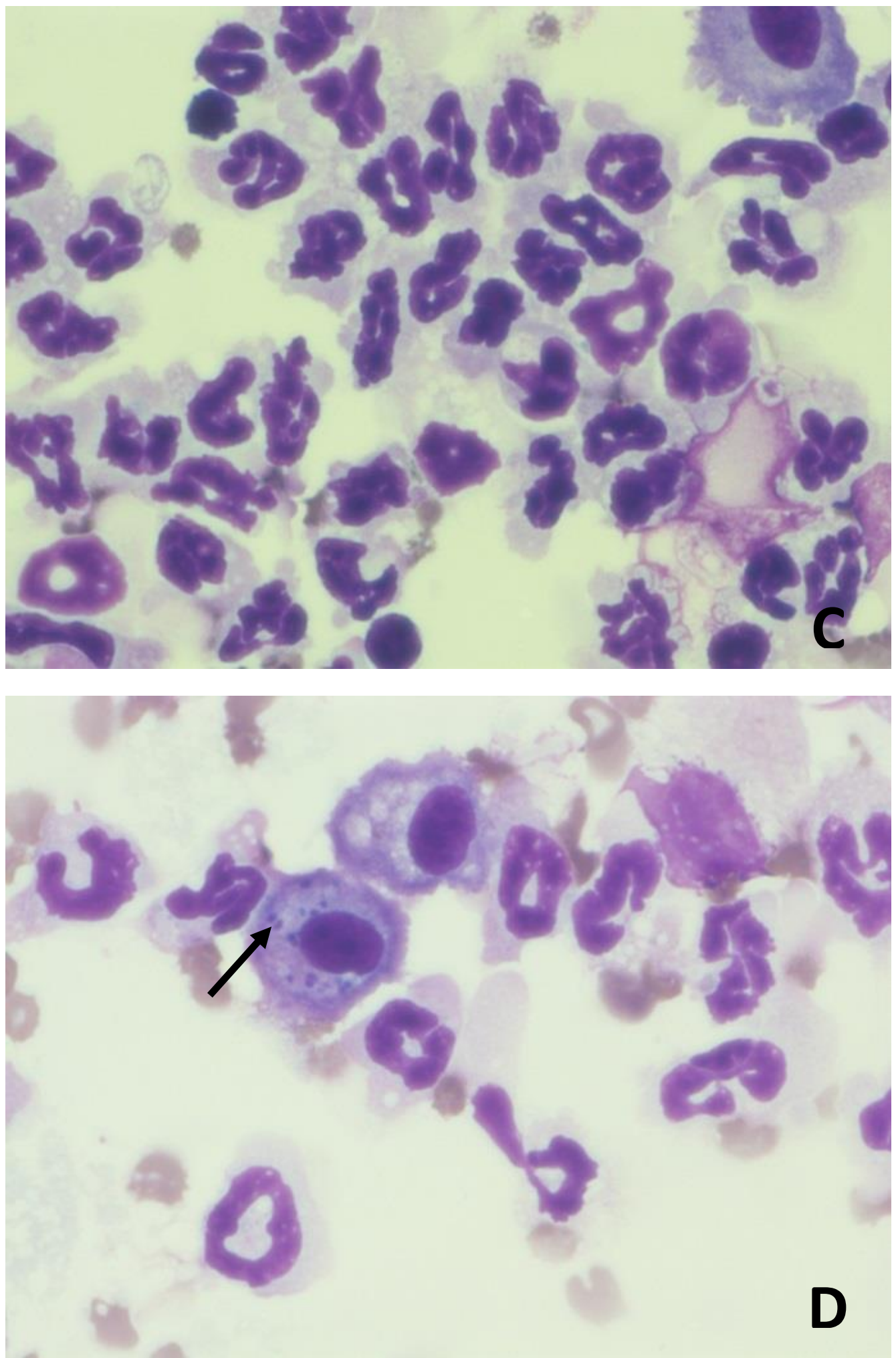